\title{
Work of breathing, not dysoxia, as the cause of low central venous blood $\mathrm{O}_{2}$ saturation in sepsis
}

\section{Guillermo Gutierrez(D)}

The review by Nguyen et al. [1] acknowledges the substantially lower baseline central venous oxygen saturation $\left(\mathrm{S}_{\mathrm{cv}} \mathrm{O}_{2}\right)$ values reported by Rivers et al. [2] (48.6 \pm $11.2 \%)$ when compared to those for ProCESS [3] (71 \pm $13 \%)$, ARISE [4] (72.7 $\pm 10.5 \%)$ and ProMISe [5] (64 \pm $20 \%)$ trials. Assuming normality, the distribution of baseline $\mathrm{S}_{\mathrm{cv}} \mathrm{O}_{2}$ values in the study by Rivers et al. differed from those of the other trials (Fig. $1 ; p<0.0001$ by $t$ test). Nguyen et al. ascribed this difference to "earlier central venous catheter (CVC) placement, greater shock severity or imbalances between $\mathrm{O}_{2}$ delivery and $\mathrm{O}_{2}$ consumption before corrective interventions".

One aspect of these trials that has been ignored up to now is the CVC position in the superior vena cava. According to accepted guidelines, the tip of the CVC should lie below the anterior first rib and above the right atrium, placing the tip of the CVC below the opening of the azygos vein, a vessel carrying venous blood from the intercostal muscles and portions of the diaphragm.

In the study by Rivers et al., $53.8 \%$ of patients randomized to the early goal-directed therapy (EGDT) group required invasive mechanical ventilation during the first $6 \mathrm{~h}$ of treatment, a greater rate $(p<0.0001$; Chi Square test) than those reported by ProCESS (26.4 \%), ARISE (22.2 \%), and ProMISe (19\%). Furthermore, the baseline respiratory rate for the EGDT cohort in Rivers et al. $(31.8 \pm 10.8 \mathrm{bpm})$ was greater $(p<0.001)$ than those reported by ProCESS $(25.4 \pm 7.0 \mathrm{bpm})$ and ARISE $(24 . \pm 7.5 \mathrm{bpm})$. The baseline respiratory rate for patients in the ProMISe trial was not reported.

These data infer that patients in the study of Rivers et al. experienced considerable respiratory distress prior to the initiation of mechanical ventilation. This condition was likely associated with an increased work of breathing and the discharge of highly desaturated blood by the

Correspondence: ggutierrez@mfa.gwu.edu

Pulmonary, Critical Care and Sleep Medicine Division, The George

Washington University MFA, 2150 Pennsylvania Ave, NW, Washington, DC 20037, USA

(c) 2016 The Author(s). Open Access This article is distributed under the terms of the Creative Commons Attribution 4.0 International License (http://creativecommons.org/licenses/by/4.0/), which permits unrestricted use, distribution, and reproduction in any medium, provided you give appropriate credit to the original author(s) and the source, provide a link to the Creative Commons license, and indicate if changes were made. The Creative Commons Public Domain Dedication waiver (http://creativecommons.org/publicdomain/zero/1.0/) applies to the data made available in this article, unless otherwise stated. azygos vein into the superior vena cava, in close proximity to the fiber optic lumen of the catheter tip, precisely where $\mathrm{S}_{\mathrm{cv}} \mathrm{O}_{2}$ was measured spectrophotometrically.

It is reasonable, therefore, to propose that the low $\mathrm{S}_{\mathrm{cv}} \mathrm{O}_{2}$ values reported in the study of Rivers et al. reflected work by the muscles of respiration and not sepsis-associated systemic tissue dysoxia. In that instance, the $\mathrm{S}_{\mathrm{cv}} \mathrm{O}_{2}$ increases observed during the first $6 \mathrm{~h}$ of treatment in the study by Rivers et al. may have been in response to unloading of respiratory muscles by mechanical ventilation and not to red blood cell transfusion or dobutamine infusion as proposed by their treatment algorithm.

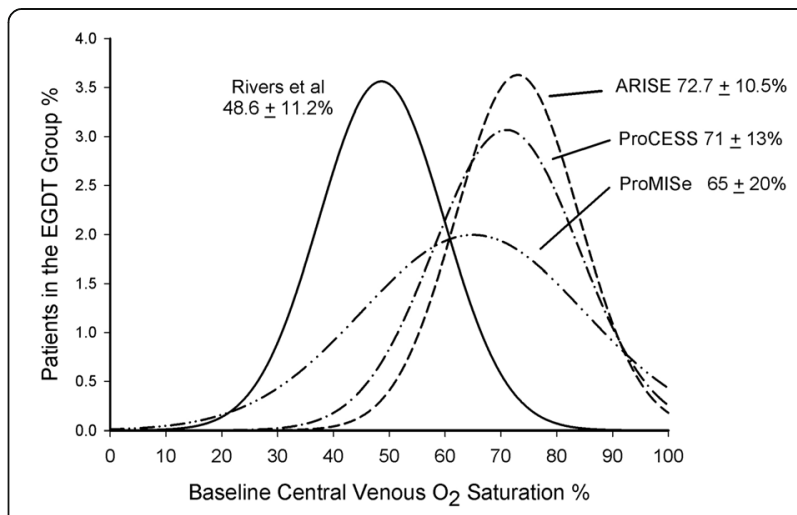

Fig. 1 Gaussian distributions for baseline $\mathrm{S}_{\mathrm{CV}} \mathrm{O}_{2}$ reported by Rivers et al [2], ProCESS [3], ARISE [4] and ProMISe trials [5]. Baseline $\mathrm{S}_{\mathrm{CV}} \mathrm{O}_{2}$ was substantially lower in the Rivers et al trial when compared to each of the other trials $(p<0.0001)$

\section{Abbreviations}

CVC: Central venous catheter; EGDT: early goal-directed therapy; $\mathrm{S}_{\mathrm{Cr}} \mathrm{O}$ : Central venous oxygen saturation

\section{Competing interests}

The author declares that he has no competing interests.

Published online: 19 September 2016 \\ ( Biomed Central}


References

1. Nguyen HB, Jaehne AK, Jayaprakash N, Semler MW, Hegab S, Yataco AC Tatem G, Salem D, Moore S, Boka K, Gill JK, Gardner-Gray J, Pflaum J,

Domecq JP, Hurst G, Belsky JB, Fowkes R, Elkin RB, Simpson SQ, Falk JL,

Singer DJ, Rivers EP. Early goal-directed therapy in severe sepsis and septic shock: insights and comparisons to ProCESS, ProMISe, and ARISE. Crit Care. 2016;20:160.

2. Rivers E, Nguyen B, Havstad S, Ressler J, Muzzin A, Knoblich B, et al. Early goal-directed therapy in the treatment of severe sepsis and septic shock N Engl J Med. 2001;345(19):1368-77.

3. Process Investigators, Yealy DM, Kellum JA, Huang DT, Barnato AE, Weissfeld $L A$, et al. A randomized trial of protocol-based care for early septic shock. N Engl J Med. 2014;370(18):1683-93.

4. ARISE Investigators, Anzics Clinical Trials Group, Peake SL, Delaney A, Bailey M, Bellomo R, Cameron PA, et al. Goal-directed resuscitation for patients with early septic shock. N Engl J Med. 2014;371(16):1496-506.

5. Mouncey PR, Osborn TM, Power GS, Harrison DA, Sadique MZ, Grieve RD, et al. Trial of early, goal-directed resuscitation for septic shock. N Engl J Med. 2015;372(14):1301-11. 